\title{
Relationship between Toxoplasma gondii exposure and Forest Cover and Precipitation in Neotropical Primates of Costa Rica
}

\author{
Carmen Niehaus ${ }^{1}$, Manuel Spínola ${ }^{2}$, Chunlei $\mathrm{Su}^{3}$, Norman Rojas ${ }^{1}$, Oscar Rico-Chávez ${ }^{4}$, \\ Carlos Ibarra-Cerdena ${ }^{5}$, Janet E. Foley ${ }^{6}$, Gerardo Suzán ${ }^{7}$, Gustavo Gutiérrez-Espeleta ${ }^{1}$, \\ and Andrea Chaves ${ }^{7}$ \\ ${ }^{1}$ Universidad de Costa Rica \\ ${ }^{2}$ Universidad Nacional de Costa Rica - Campus Omar Dengo \\ ${ }^{3}$ University of Tennessee \\ ${ }^{4}$ Universidad Nacional Autonoma de Mexico \\ ${ }^{5}$ Centro de Investigación y de Estudios Avanzados del IPN (Cinvestav), Unidad Mérida \\ ${ }^{6}$ University of California Davis \\ ${ }^{7}$ Affiliation not available
}

June 11, 2020

\begin{abstract}
The apicomplexan parasite Toxoplasma gondii has been found in more than 350 species of homoeothermic vertebrates in diverse climates and geographic areas. In most animals, T. gondii produces mild or asymptomatic infection. However, acute and hyperacute toxoplasmosis is associated with high mortality rates observed in Neotropical primates (NP) in captivity. NP are distributed in 20 countries across the Americas, and although infection has been reported in certain countries and species, toxoplasmosis in the wild and its impact on NP population survival is unknown. Differences among species in exposure rates and disease susceptibility may be due in part to differences in host behavior and ecology. Costa Rica has four species of NP, howler (Alouatta palliata), spider (Ateles geoffroyi), capuchin (Cebus imitator), and squirrel monkeys (Saimiri oerstedii). Here we report for the first time NP exposure to T. gondii using a modified agglutination test (MAT) in 245 serum samples of NP (198 wild and 47 from captivity) from Costa Rica. Associations of serostatus with environmental (forest cover, annual mean temperature), anthropogenic (human population density), and biological (sex) variables in howler and capuchin monkeys were evaluated. The seroprevalence among wild NP was $11.6 \%$ (23/198), compared with 60\% (28/47) in captive monkeys, with significant differences between species $(\mathrm{P}<0.05)$, suggesting behavior and ecology influences. In general, antibody titers were low for wild NP $(<128)$ and high for captive NP (>8192), suggesting higher exposure due to management factors and increased life span in captivity. Seropositivity in howler monkeys was positively related to forest cover and inversely related to annual rainfall. For capuchins, annual rainfall was inversely related to seropositivity. Surveillance of T. gondii in NP in captivity and in the wild is required to understand drivers of the infection and develop novel strategies to protect them.
\end{abstract}

\section{Title:}

Relationship between Toxoplasma gondii exposure and Forest Cover and Precipitation in Neotropical Primates of Costa Rica

\section{Short running title:}

Toxoplasma gondii in Neotropical Primates

Carmen Niehaus ${ }^{1,2}$, Manuel Spínola ${ }^{3}$, Chunlei $\mathrm{Su}^{4}$, Norman Rojas ${ }^{5}$, Oscar Rico-Chávez ${ }^{6}$, Carlos N. IbarraCerdeña $^{7}$, Janet Foley ${ }^{8}$, Gerardo Suzán ${ }^{6}$, Gustavo A. Gutiérrez-Espeleta ${ }^{1}$, Andrea Chaves ${ }^{1,8, *}$. 
${ }^{1}$ Escuela de Biología, Universidad de Costa Rica.

${ }^{2}$ Posgrado Regional en Ciencias Veterinarias Tropicales, Universidad Nacional de Costa Rica.

${ }^{3}$ Instituto Internacional de Conservación y Manejo de Vida Silvestre, Universidad Nacional de Costa Rica.

${ }^{4}$ Department of Microbiology, College of Arts and Sciences, University of Tennessee, Knoxville.

${ }^{5}$ Centro de Investigación en Enfermedades Tropicales, Facultad de Microbiología, Universidad de Costa Rica.

${ }^{6}$ Departamento de Etología, Fauna Silvestre y Animales de Laboratorio, Facultad de Medicina Veterinaria y Zootecnia, Universidad Nacional Autónoma de México.

${ }^{7}$ Departamento de Ecología Humana, Centro de Investigaciones y de Estudios de Avanzados del IPN (Cinvestav), Unidad Mérida, Mérida.

${ }^{8}$ Department of Medicine and Epidemiology, School of Veterinary Medicine, University of California, Davis.

*Corresponding author: Andrea Chaves

E-mail address: andreachaves.biol@gmail.com

Summary:

The apicomplexan parasite Toxoplasma gondii has been found in more than 350 species of homoeothermic vertebrates in diverse climates and geographic areas. In most animals, T. gondii produces mild or asymptomatic infection. However, acute and hyperacute toxoplasmosis is associated with high mortality rates observed in Neotropical primates (NP) in captivity. NP are distributed in 20 countries across the Americas, and although infection has been reported in certain countries and species, toxoplasmosis in the wild and its impact on NP population survival is unknown. Differences among species in exposure rates and disease susceptibility may be due in part to differences in host behavior and ecology. Costa Rica has four species of NP, howler (Alouatta palliata), spider (Ateles geoffroyi), capuchin (Cebus imitator), and squirrel monkeys (Saimiri oerstedii ). Here we report for the first time NP exposure to T. gondii using a modified agglutination test (MAT) in 245 serum samples of NP (198 wild and 47 from captivity) from Costa Rica. Associations of serostatus with environmental (forest cover, annual mean temperature), anthropogenic (human population density), and biological (sex) variables in howler and capuchin monkeys were evaluated. The seroprevalence among wild NP was $11.6 \%$ (23/198), compared with $60 \%$ (28/47) in captive monkeys, with significant differences between species $(\mathrm{P}<0.05)$, suggesting behavior and ecology influences. In general, antibody titers were low for wild NP $(<128)$ and high for captive NP $(>8192)$, suggesting higher exposure due to management factors and increased life span in captivity. Seropositivity in howler monkeys was positively related to forest cover and inversely related to annual rainfall. For capuchins, annual rainfall was inversely related to seropositivity. Surveillance of T. gondii in NP in captivity and in the wild is required to understand drivers of the infection and develop novel strategies to protect them.

Keywords:

Serology, Alouatta palliata, Ateles geoffroyi , Cebus imitator, Saimiri oerstedii, endoparasites, Latin America

\section{Main text:}

\section{Introduction}

Toxoplasma gondii is an obligate intracellular parasite that can infect more than 350 species of mammals and birds worldwide (Dubey, 2010; Lindsay \& Dubey, 2007; Tenter et al., 2000). It is the single species within its genus, in the phylum Apicomplexa (Roberts \& Janovy Jr. 2000). The parasite (Dubey et al., 1970) undergoes sexual reproduction to produce oocysts in most domestic and wild felids, which function as definitive hosts $(\mathrm{DH})$ and excrete oocysts in their feces. Oocysts are the infective stage for intermediate hosts (IH), and thus, felid latrines are a source of contamination for IH (VanWormer et al., 2013). T. gondii can also spread 
asexually, often via ingestion of encysted organisms in tissue (Su et al., 2003), allowing the parasite to bioaccumulate in IH such as carnivores and scavengers. In addition, several species of cockroaches, earthworms, and beetles function as mechanical hosts (Dubey, 2010; Chinchilla et al., 1994).

Seroprevalence of antibodies against T. gondii in hosts varies spatially (Afonso et al 2010) and temporally, and is influenced by climate (Salant \& Spira, 2004; Afonso et al., 2010). For example, higher seroprevalence has been observed during years with high temperatures or high rainfall in humans (Hubálek, 2005), rabbits (Almeria et al., 2004), wild ruminants (Gamarra et al., 2008), and domestic cats (Afonso et al., 2006; 2010; 2013). Risk is often moderated through impacts on the distribution of domestic and wild cats, which are influenced by human factors such as the presence of prey, intra or inter-specific territorial interactions, environmental stress, vegetation, and topography (Horn et al., 2011).

Host-specific factors also influence susceptibility to $T$. gondii, with higher prevalence sometimes detected in larger rodents and lagomorphs than smaller ones (Afonso et al., 2007), and in species with a longer life expectancy (De Thoisy et al., 2003). This may be due to greater exposure to oocysts in species with larger home ranges, longer life expectancies, and higher energy requirements, which are related to body size (Ottaviani et al., 2006). Male cats have a five times greater chance of having antibodies than females (Afonso et al., 2007), possibly due to having larger body sizes and greater need to consume more and larger prey than females (Niewold, 1986). In French Guiana, burrowing, granivorous, and insectivorous mammals had much higher prevalences than arboreal ones (Carme et al., 2002). Mammals in terrestrial or mixed terrestrial / arboreal habits were more exposed to oocysts than strictly arboreal ones (Thoisy et al., 2003; Nardoni et al., 2011).

Among Neotropical primates (NP), the intensity of T. gondiipathology varies among infected species: such differences could be due in part to differences in ecology and behavior (Catão-Dias et al., 2013). Toxoplasmosis in the Callitrichinae NP subfamily (Saguinus, Leontopithecus, Callithrix ) may cause almost 100\% mortality, resulting in very low seroprevalence and contributing to difficulty in making ante-mortem diagnosis, particularly in free-ranging populations. NP in the Saimiri and Aotus genera of Cebidae and Atelesand Alouatta in Atelidae may experience acute and severe signs including prostration, anorexia, hypothermia, dyspnea, and vomiting, with mortality from 20-80\%, allowing for seroprevalence of 15-66\% (Catão-Dias et al., 2013). In contrast, signs among Cebus sp. NP are usually subacute and moderate, with a very low mortality rate that generates high and persistent IgG titers (Bouer et al 2010). Reports in captivity range from 28-79\% of infected Cebus sp. monkeys, compared with $30.2 \%$ of animals in the wild (Garcia et al., 2005; Leite et al., 2008; Bouer et al., 2010). Cebus sp. NP may have evolved greater resistance than other NP species after frequent exposure to T. gondii (Catão-Dias et al., 2013). Cebus sp. NP commonly forage for insects on the ground and drink water from puddles and water holes, where they may encounter oocysts (Fragaszy et al., 2004). In addition, although most of the Cebus diet protein comes from invertebrates, they may consume a variety of vertebrates weighing up to $1 / 3$ of their body weight and constituting up to $3 \%$ of their feeding time (Fragaszy et al., 2004).

In Costa Rica there are four species of NPs. While the Central American white-faced capuchin (Cebus imitator ) and the Mantled howler monkey (Alouatta palliata) are considered at low risk (least concern) according to IUCN Red List, Geoffroy's spider monkey (Ateles geoffroyi ) and both subspecies of the Central American squirrel monkey (Saimiri oerstedii oerstedii and S. o. citrinellus ) are endangered mainly due to habitat loss and fragmentation (Cuarón et al., 2008a-e). Some species still are captured for the illegal pet trade, and are thus protected from international trade under Appendix I of the Convention on International Trade in Endangered Species (CITES, 2020). Although Costa Rica has protected areas that cover $25 \%$ of the country (González \& Lobo, 1999), other conservation actions include a system of incentives to farmers known as payments of environmental services (PEP) since 1997 (Pagiola, 2008), and a national program of biological corridors (PNCB) to increase connectivity between forest patches, species migration and genetic flow (La Gaceta, 2006, SINAC, 2008). Ex situ actions include keeping some NP in zoos for education purposes and rescue centers across the country focus on rehabilitation and reintroduction of individuals back to protected areas. 
The high mortality rates observed in some NP can imperil already at-risk populations, but the causes of mortality and high rates of exposure are poorly understood (Bouer et al., 2010; Catão-Dias et al., 2013), so it is important to assess the infection status in captive NP. Living in altered environments or in contact with humans (where domestic cats are present) can affect NP behavior (McKinney, 2011) and exposure to infectious agents (Wolfe et al., 1998, Ekanayake et al 2004). Thus, it is important to evaluate impacts of $T$. gondii infection in NP in different areas that experience differential contact with human-altered habitat and have differing behaviors and diet (Fragaszy et al., 2004; Catão-Dias et al., 2013). Here we analyzed exposure to T. gondiiin A. geoffroyi, A. palliata, C. imitator and S. oerstedii and the influences of environmental, anthropogenic, and biological variables in wild $A$. palliata and C. imitator in Costa Rica.

\section{Materials and methods}

\section{Study area}

The small tropical country of Costa Rica is located in southern Central America (latitudes $802^{\circ} 26^{\circ}$ and 11 $13^{`} 12^{`} \mathrm{~N}$, and longitudes $8233^{`} 48^{\text {"and }} 8557^{\circ} 57^{\prime \prime} \mathrm{W}$ ) and has an area of $51,100 \mathrm{~km}^{2}$ (with around $5 \%$ of the biodiversity in the planet). After having one of the world's highest deforestation rates during the 1970s, laws were changed and today, forested areas represent $52 \%$ of the country (MINAET and FONAFIFO, 2012), and $25 \%$ are protected (González \& Lobo, 1999). The land's volcanic origin and its steep elevation gradients influence the country's heterogeneity, which has 12 life zones distributed from intertidal zones to over 3000 meters above sea level (Holdridge \& Grenke, 1971). Precipitation varies seasonally, being the highest from May to early November, and spatially, with wettest regions receiving over $7000 \mathrm{~mm}$ of rainfall per year, and the driest receiving around $900 \mathrm{~mm}$ (Avalos, 2019).

\section{Sampling}

This study used 245 serum samples from four species of native NP (C. imitator, A. palliata, A. geoffroyi and $S$. oerstedii ) collected throughout Costa Rica in 2000-2015 as part of the project "Epidemiological, genetic, ethological and habitat studies in Costa Rica's monkeys" (Resolution 27-2013- National System of Conservation Areas, Figure 1.A.). Of the 245 NP, 198 were wild and 47 were in captivity. Most samples from captive animals came from three rescue centers, although 12 different sites were sampled. NP were anesthesized using IM injection of $3.3-11 \mathrm{mg} / \mathrm{kg}$ of Zoletil $50 \AA$ or $5-20 \mathrm{mg} / \mathrm{kg}$ ketamine with $0.5-2 \mathrm{mg} / \mathrm{kg}$ xylazine (Glander et al., 1991; Varela, 2006; West et al., 2007), which for wild NP was loaded into darts (PneuDart. Inc, Type P, 1cc) and delivered using a compressed gas rifle (PneuDart. Inc, model X-Caliber Gauged CO2) targeting the lateral triceps and quadriceps femoris (Glander et al., 1991). After an individual was anesthetized, blood was sampled from the femoral vein and placed into a cooler at $4^{\circ} \mathrm{C}$. Once in the laboratory, samples were centrifuged at 2500 RPM for 5 minutes to separate serum, which was transferred to sterile $1.5 \mathrm{ml}$ tubes at $-20^{\circ} \mathrm{C}$ until processed. Animals underwent a physical examination and were released upon awakening from anesthesia.

\section{Serological analysis}

A modified agglutination test (MAT) was used to detect immunoglobulin G (IgG) specific for T. gondii as previously described by Desmonts and Remington (1980), and Dubey and Desmonts (1987). Formalin-fixed tachyzoites were used as antigen $\left(2 \times 10^{8}\right.$ tachyzoites/mL from KeraFAST Inc., Boston, MA, USA. Catalog No. EH2002). Sera were serially diluted in buffered saline solution (1X PBS) from 1/4 to 1/8192 in 96-well round bottom microplates and $25 \mathrm{ul}$ of antigen mixture $(2.5 \mathrm{ml}$ alkaline buffer, $35 \mathrm{ul}$ 2-mercaptoethanol, $50 \mathrm{ul}$ Evans blue dye $\left(2 \mathrm{mg} / \mathrm{ml}\right.$ in $\left.\mathrm{H}_{2} \mathrm{O}\right)$ and $150 \mathrm{ul}$ T. gondii MAT antigen) were added to each well. The microplates were covered with sealing tape and incubated at $37^{\circ} \mathrm{C}$ for 24 hours and subsequently for 4 hours at $4^{\circ} \mathrm{C}$. A positive reaction was characterized by a complete "mesh" of agglutination and a clear bottom, while sedimentation of antigen suspension in the form of a blue pellet at the bottom of the well was considered to be a negative reaction. Sera from mice and/or humans with a titer of $1 / 200$ or greater were included as positive controls and negative controls were also included with each group of processed sera. All antibody titers that were $1 / 16$ or higher were reported as positive. Titer values from captive versus free ranging primates were analyzed using a Mann-Whitney two tailed test to know if there are significant 
differences at a 0.05 alpha value.

\section{Biological, Environmental, and Anthropogenic Drivers}

Due to insufficient sample size, data for $A$. geoffroyi and $S$. oerstedii were not included for further statistical analyses. Seven independent variables were explored for their association with exposure to T. gondii in $A$. palliata and C. imitator. Distance to villages, human population size, and human population density in the nearest village were considered indirect indicators of proximal domestic cats. The percentage of forest cover, annual average temperature, and annual precipitation were used as variables that affect oocyst survival. NP sex was used as an intrinsic factor for oocyst exposure (Table 1).

Forest cover, annual average temperature, and annual precipitation were measured within a $1.54 \mathrm{~km}^{2}$ circular area (700 m radius) that was constructed around each sample's geolocation point (QGIS software, version 2.14). Data for these variables were obtained from Costa Rica Digital Atlas (2014) and WorldClim (Hijmans et al., 2005). The buffer size aimed to include both species' home ranges and adjacent areas (Wainwright 2007).

Generalized linear models (GLM) with binomial distribution were run in R V3.4.2 (R Core Team, 2013) to explore associations between predictor variables and T. gondii seropositivity. The original predictors (forest cover and precipitation) were centered by subtracting their means and scaled by dividing by their standard deviations. The most parsimonious model was chosen by selecting the one with the lowest Akaike information criterion (AIC). Akaike weights (wi) were calculated to determine the evidence in favor of each model and estimate the relative importance of variables (Table 2).

Each NP species was modeled separately. Multicollinearity among the seven variables was evaluated by means of the variance inflation factor (VIF). When analyzing all the proposed variables, a very high VIF value $(>10)$ was obtained suggesting multicollinearity, therefore the model was reduced to four variables (sex, forest cover, annual precipitation, and human population density). With these models, none of the variables obtained a VIF value greater than 10 (Table 2).

\section{Results}

T. gondii -specific IgG antibodies were found in 59.6\% (28/47) of captive NPs and $11.6 \%(23 / 198)$ of wild NPs. In captive NPs, seroprevalence was high for both species: $59.1 \%(26 / 44)$ of A. geoffroyi and $66.7 \%$ $(2 / 3)$ of $C$. imitator . There were no significant differences in species or sex with $58.6 \%$ (17/29) of $A$. geoffroyi females and $60.0 \%$ (9/15) males being positive, while for C. imitator , $50.0 \%$ (1/2) females and 100\% (1/1) male had antibodies (Table 3, Table 4).

In contrast, there was a significant difference in seroprevalence among wild NP species $\left(X^{2}=20,072 ; d f=\right.$ $3 ; P=0.0002): A$. geoffroyi had the highest seroprevalence with $40 \%(2 / 5)$, followed by $C$. imitator with $30 \%(11 / 37)$ and A. palliata with $6.6 \%$ (10/151), while no $S$. oerstediiwere positive. No significant differences were found regarding sex for any of the species, however, greater seroprevalence was observed for females in the three positive species (Table 3, Table 5).

Antibody titers tended to be relatively low $($ Median $=8)$ in wild NP $(<128)$, with the exception of four individuals: one A. geoffroyi and two C. imitator with antibody titers of 262,144 and one A. geoffroyi with a titer of $1,048,576)$. In contrast, antibody titers were considerably higher (Median $=262144$ ) in captive NP, from 8,192 to 33,554,000 (Table 6). These two groups of NP were statistically different in their titer values (Mann-Whitney $\mathrm{U}=303, \mathrm{n} 1=52, \mathrm{n} 2=34, \mathrm{p}<0.00001$ two tailed).

The model that best accounted for seropositivity among A. palliata (minimizing AIC) was forest cover and annual precipitation (Figure 1.B., Table 2), with a positive relationship between forest cover and seropositivity and inverse relationship with annual precipitation. However, evidence weights (wi) for the second and third best-supported models were 1.02 and 1.94 times lower than model 1 respectively, which suggests that no one model is strongly supported as the best candidate. The second best model was annual precipitation 
$(\Delta \mathrm{AIC}=0.04)$ and the third was for human population density and annual precipitation $(\Delta \mathrm{AIC}=1.32)$. Notably, the precipitation parameter appeared among the top eight models.

For C. imitator, annual precipitation alone best accounted for seropositivity with a significant inverse relationship (Figure 1.C., Table 2). The next best models were forest cover and annual precipitation $(\Delta \mathrm{AIC}=$ $1.09)$ and human population density and precipitation $(\Delta \mathrm{AIC}=1.5)$, with evidence weights 1.73 and 2.12 times lower than model 1, respectively. Again, the effect of precipitation on seropositivity was important for C. imitator when comparing the sum of the weights of Akaike (wi) in the models that contained this variable $(0.98)$ with respect to the others, such as forest cover (0.35), population density (0.3) and sex (0.29).

\section{Discussion}

Our survey of T. gondii in NPs across Costa Rica documented widespread infection and species-specific risks of infection. The seroprevalence obtained for captive NPs is similar to other studies in South America, such as 30.8\% and 76\% using MAT in captive Cebus apella, (Leite et al., 2008; Pires et al., 2012), and 79\% inCebus sp. and 57\% in Ateles sp. from zoos in São Paulo, Brazil (Bouer et al., 2010). The high prevalence of NPs in captivity may be due to management practices, including improperly washed fruits or vegetables, and raw or undercooked meat (Pires et al., 2012; Valentini et al., 2004), proximity of wild or domestic cats, and invasion of enclosures by infected birds and rodents that might be ingested by NPs (Pires et al., 2012; Valentini et al., 2004). These sources of infection would be similar for male and female NPs in captivity, consistent with our findings.

The $11.6 \%$ seroprevalence in wild Costa Rican NPs was lower than the $26.6 \%(\mathrm{n}=60)$ reported by Garcia et al (2005) using MAT in Brazil, and the prevalence we found for A. palliata $(6.6 \%)$ is lower than documented for Alouatta caraya by Garcia et al (2005) in Paraná (17\%, 3/17) and Molina et al (2014) in São Paulo, Brazil $(75 \%, 15 / 20)$. However, it is very similar to findings by de Thoisy et al (2001), who found only $4 \%$ (2/50) seropositive Alouatta senilicus in French Guiana, and similar to this study had a higher proportion of positive females. Our data did not indicate a significant difference between sexes for any of the species, although this should be studied further given the sex bias observed in French Guiana and among domestic cats (Afonso et al., 2007).

In the case of $C$. imitator, the prevalence is equal to that reported by Garcia et al. (2005) in Cebus spp. with $30.2 \%(13 / 43)$. In fact, several studies have identified that carnivorous diet is a risk factor for T. gondii infection (Cabezón et al., 2011; Hejlicek et al., 1997). On the other hand, the prevalence found in A. geoffroyi $(40 \%, 2 / 5)$ appears to be high, which is surprising considering its arboreal and herbivorous (frugivorous) behavior, characteristics that minimize its exposure to the parasite. No prevalence reports were found for wild Ateles sp. to compare this finding to. However, sample sizes for both A. geoffroyi and $S$. oerstedii were very small, so these findings should be interpreted with caution. The difference in seropositivity observed between howler (A. palliata) and capuchin monkeys (C. imitator) coincides with Garcia et al. (2005) and corresponds to behavioral characteristics between species. Howlers are predominantly folivorous, supplementing their diet with fruits, flowers and seeds, and obtaining most of the water they need from their food (reviewed by Wainwright, 2007). However, they can drink from water accumulated in branches, trunks or bromeliads (Glander, 1978; Gilbert \& Stouffer, 1989), or search for it on the ground (Almeida-Silva et al., 2005). The source of infection for howlers would be water bodies infected with oocysts. Meanwhile, capuchins are the most omnivorous NPs, feeding on various sources like fruits, insects and small vertebrates such as birds, rodents, squirrels, coatis, bats, frogs and lizards (reviewed by Wainwright 2007 and Catão-Dias et al., 2013). They frequently go down to the undergrowth and ground while foraging and traveling (Feagle, 1999). In addition, Cebus spp. drink water directly from puddles (Fragaszy et al., 2004). These characteristics give capuchins greater exposure to oocysts in the soil / water or in invertebrates (transport hosts) and to tissue cysts present in infected vertebrates.

The low antibody titers obtained for the wild NPs (16 and 32) coincide with those reported by Garcia et al. (2005), who found mostly 16 and 32 for a single individual. While A. palliata had low antibody titers, two A. geoffroyi and two C. imitator had very high antibody titers $(262,144-1,048,576)$. Molina et al 
(2014) reported values of 25 for Callithrix penicillata (a very susceptible species) and higher titers (up to 1600) for A. caraya, arguing that differences in prevalence and titers could respond to differences in host susceptibility, contact rates or post-exposure time. Indeed,Alouatta 's susceptibility in comparison to Cebus could be reflected in serological differences, since the probability of post-infection survival and, therefore, developing an immune response is naturally lower for howlers. Furthermore, if these individuals die, they would be excluded from the population and the sample, reducing the number of individuals captured with high titers. In contrast, titers of captive NPs were high in our study. Leite et al. (2008) reported antibody titers of 8000 by MAT for Cebus sp . in captivity, while Ekanayake et al. (2004) reported antibody titers $>256$ (up to 4096) in 3 of 21 positive free-ranging but urban macaques in Sri Lanka. Management factors along with the increased life expectancy forCebus sp. and Ateles sp. in captivity could explain the chance of infection and high titers observed in this group.

It is worth highlighting the large number of positive samples from the Gulf of Nicoya (Figure 1.A.). Tempisque River is one of the most important basins in the country, draining $10.6 \%$ of the territory and flowing into the Gulf of Nicoya (Gutierrez et al 1985). Areas close to bodies of water could represent sources of infection for NP, because water can be contaminated at any point, transport oocysts long distances, and favor their survival (Lindsay \& Dubey, 2009). Samples from protected areas with high levels of human contact also showed high prevalence and high titers in the two wild $C$. imitator mentioned before. In certain national parks and private reserves, feeding wild monkeys is a common practice, and capuchin and squirrel monkeys sometimes exhibit agonistic behaviors that include taking food directly from humans and coming down to the ground. Such opportunistic behavior (Campbell, 2013) may increase exposure to infectious agents (Wolfe et al., 1998; Ekanayake et al., 2004).

Besides identifying specific areas where there could be elevated risk of infection, our data indicates that environmental variables such as forest cover and precipitation could be associated with exposure risk. Seropositivity in A. palliata was higher when there was a higher percentage of forest cover and less annual precipitation. Forest cover can protect oocysts from sunlight, allowing them to remain viable where protected for 1-1.5 years (Ruiz et al., 1973; Frenkel et al., 1975). Smith \& Frenkel (1995) and Almeria et al. (2004) found greater seroprevalence in hares and other mammals sampled in forested areas versus more arid grasslands, arguing that shadow and relative humidity provided by forest cover act on oocyst conservation by decreasing the evaporation rate and desiccation of oocysts.

Wet seasons tend to increase oocyst survival (Frenkel et al., 1975). In fact, T. gondii seroprevalence in cats (Afonso et al., 2013) and humans (Hubalek 2005) has been associated with rainy and warm episodes (North Atlantic Oscillation), and in wild ruminants (Gamarra et al., 2008) with humid areas. Contrary to expectations, in this study precipitation was inversely related with seropositivity in both NP species. Costa Rica is a tropical country with high relative humidity and stable temperature overall. It is possible that increased precipitation in Costa Rica results in greater runoff, transporting oocysts towards the coasts and away from the animals. In recent past years, low rainfall due to the El Nino phenomenon has generated severe droughts and forest fires in some areas of Costa Rica. Among many other animals, A. palliata were severely affected by water and food shortages, with high mortality due to dehydration and starvation, as well as injuries due to troops fighting for food. Because behavior change driven by droughts can increase exposure to parasites present in the scarce sources of water, the risk of disease increases especially for animals weakened by starvation and dehydration.

In the present study, the source of exposure of wild NP could be wild and not domestic cats, which might explain the low effect of human population density on seropositivity. Contact with humans has been associated with high seropositivity in macaques (Ekanayake et al., 2004), which can become infected by ingesting human food from the ground in areas frequented by domestic cats (Tenter et al., 2000). Domestic cat population estimates as well as sampling in areas where humans feed and interact with wildlife should be included in future studies.

Additionally, Toxoplasma genotypes produce different degrees of virulence in humans and mice (Xiao \& Yolken, 2015), and given the high diversity recently found in Central and South America (Ajzenberg et al., 
2004; Lehmann et al., 2004; Rajendran et al., 2012; Vitaliano et al., 2014; Rego et al., 2018; Vethencourt et al., 2019) the observed differences in seroprevalence between wild and captive NP might be due to different genotypes. Little is known about the genotypes circulating in wildlife, and associations between strain type, lesion patterns and clinical outcome have not been reported in wildlife frequently. Thus, future studies that focus on genotyping and virulence of T. gondii isolates in wildlife and domestic animals from wild and anthropized environments would be of great value.

In the present study, MAT was used as it is simple and fast, doesn't require specific modifications, can be used for large sample sizes and diverse host species, and can be run on serum and plasma (Desmonts \& Remington, 1980; Shaapan et al., 2008; Dubey, 2010). An antibody titer of $1 / 25$ is often considered as evidence of exposure to T. gondiiin many mammals (Dubey et al., 1995) and 1/5 in birds (Dubey et al., 2016). However, there is no antibody titer that is considered specific for primates and our analysis required that we be able to maximize sensitivity of detection given the high susceptibility and low seroprevalence in some NP species, thus we reported all antibody titers of $1 / 16$ or higher (Garcia et al., 2005).

Among the reagents used for MAT is mercaptoethanol which destroys immunoglobulin M (IgM) and therefore MAT only detects IgG (Seefeldt et al., 1989). Because IgG are maintained for life (Dubey, 2010), their detection indicates exposure to T. gondii at some point during the animal's life; inability to discriminate recent infections precludes assessing longitudinal shifts in seropositivity. However, IgG presence can be used to detect the spatial influences of environmental factors. Further analyses through longitudinal sampling and detection of IgM are recommended.

In conclusion, our study documented widespread T. gondiiinfection in NP and species-specific risks of infection for the first time in Costa Rica. The high seroprevalence and titers found in captive capuchin and spider monkeys may be due to management practices, the proximity of cats or intermediate hosts, and the increased life expectancy in captivity for these species. The low seroprevalence and titers in wild NP varied between species. The difference in seropositivity observed between wild howler (A. palliata) and capuchin monkeys (C. imitator ) in this study agrees with behavioral and dietary characteristics, in which capuchins are more exposed to oocysts while foraging on the ground, and by ingesting invertebrates (transport hosts) and vertebrates (tissue cysts). However,Alouatta 's susceptibility compared to Cebus might also explain the observed serological differences, due to decreased survival. Our data indicated that specific areas could represent an elevated risk of infection (i.e. water runoff and human interaction), and environmental variables such as abundant forest cover and low precipitation could be associated with higher exposure risk in wild NP. Surveillance of $T$. gondii in NP is required to better understand the infection status, genotypes and drivers involved in wild and captive NP, including individuals in the process of reintroduction, so that biosecurity measures are improved, avoiding the release of infected individuals, and develop novel strategies to protect wild populations.

\section{Acknowledgements}

We are grateful to all contributors who assisted with sampling endeavors, especially Mauricio Jimenez, Maria Isabel DiMare, Sofia Bernal, Genuar Nunez, Natalia Valverde and Mauricio Losilla. We would also like to thank the National System of Conservation Areas (SINAC), and the Ministry of Environment and Energy (MINAE) of Costa Rica. This research was carried out thanks to funding by the Cleveland Zoological Society and Cleveland Metroparks Zoo.

Ethics statement: The present study was conducted under the protocols established by the Institutional Committee for the Care and Use of Animals (Comite Institucional para el Cuidado y Uso de los Animales) of the Universidad de Costa Rica, adhered to the legal requirements of Costa Rica, and adhered to the American Society of Primatologists (ASP) Principles for the Ethical Treatment of Non-Human Primates. Collection permit number: MINAET-SINAC-Costa Rica: 042-2012-SINAC.

Data availability statement: The data that support the findings of this study are available from the corresponding author upon reasonable request. 
Author contributions statement: C.N., and A.C. conceived the investigation and wrote the article, A.C., and G.G-E collected samples, C.N., N.R., and C.S., conducted the laboratory analysis, C.N., M. S., C.I-C., A.C. and O.R-C.: performed the statistical analysis, J.F., and G.S. copy reviewed and edited. All authors reviewed the manuscript.

Conflict of interest statement: The author(s) declare no competing interests.

\section{References}

Afonso, E., Thulliez, P., \& Gilot-Fromont, E. (2006). Transmission of Toxoplasma gondii in an urban population of domestic cats (Felis catus). Int. J. Parasitol. 36, 1373- 1382.

Afonso, E., Thulliez P., Pontier, D., \& Gilot-Fromont, E. (2007). Toxoplasmosis in prey species and consequences for prevalence in feral cats: not all prey species are equal. Parasitology 134: 1963-1971.

Afonso, E., Thulliez, P., \& Gilot-Fromont, E. (2010). Local meteorological conditions, dynamics of seroconversion to Toxoplasma gondii in cats (Felis catus) and oocyst burden in a rural environment. Epidemiol. infect. 138: 1105-1113.

Afonso, E., Germain, E., Poulle, M. L., Ruette, S., Devillard, S., Say, L., Villena, I., Aubert, D., \& GilotFromont, E. (2013). Environmental determinants of spatial and temporal variations in the transmission of Toxoplasma gondii in its definitive hosts. Int J Parasitol: Parasites and Wildl. 2: 278-285.

Almeida-Silva, B., Guedes, P. G., Boubli, J. P., \& Strier, K. B. (2005). Deslocamento terrestre e o comportamento de beber em um grupo de barbados (Alouatta guariba clamitans Cabrera, 1940) em Minas Gerais, Brasil. Neotrop Primates 13:1-3.

Almeria, S., Calvete, C., Pages, A., Gauss, C.B.L., \& Dubey, J.P. (2004). Factors affecting the seroprevalence of Toxoplasma gondiiinfection in wild rabbits (Oryctolagus cuniculus ) from Spain. Vet. Parasitol. 123, 265-270.

Avalos, G. (2019). Still searching the rich coast: Biodiversity of Costa Rica, numbers, processes, patterns, and challenges. In Pullaiah, T. (ed). Global Biodiversity Volume 4: Selected countries in the Americas and Australia (pp. 101-138). Apple Academic Press, CRC.

Chinchilla, M., Guerrero, O. M., Castro, A., \& Sabah, J. (1994). Cockroaches as transport hosts of the protozoan Toxoplasma gondii . Rev Biol Trop. 42(1-2):329-31.

Bouer, A., Werther, K., Machado, R. Z., Nakaghi, A. C., Epiphanio, S., \& Catao-Dias, J. L. (2010). Detection of anti-Toxoplasma gondiiantibodies in experimentally and naturally infected non-human primates by Indirect Fluorescence Assay (IFA) and indirect ELISA. Revista Brasileira de Parasitologia Veterinaria, 19, 26-31.

Cabezon, O., Garcia-Bocanegra, I., Molina-Lopez, R., Marco, I., Blanco, J.M., Hofle, U., Margalida, A., Bach-Raich, E., Darwich, L., Echeverria, I., Obon, E., Hernandez, M., Lavin, S., Dubey, J.P., \& Almeria, S. (2011) Seropositivity and risk factors associated with Toxoplasma gondii infection in wild birds from Spain. PLoS ONE, 6(12), e29549.doi: 10.1371/journal.pone.0029549

Campbell, J. C. (2013). "White-faced Capuchins (Cebus capucinus ) of Cahuita National Park, Costa Rica: Human Foods and Human Interactions". Graduate Theses and Dissertations. Paper 13620. Retrieved from: http://lib.dr.iastate.edu/cgi/viewcontent.cgi?article=4627\&context=etd

Carme, B., Aznar C., Motard A., Demar M., \& De Thoisy B. (2002). Serologic survey of Toxoplasma gondii in noncarnivorous free-ranging neotropical mammals in French Guiana. Vector Borne and Zoonotic Dis. 2(1):11-17.

Catao-Dias, J. L., Epiphanio, S., \& Kierulff, M.C.M. (2013). Neotropical primates and their susceptibility to Toxoplasma gondii : New Insights for an Old Problem. En: Brinkworth, J.F., \& Pechenkina, K. (Eds.), 
Primates, Pathogens, and Evolution, Developments in Primatology: Progress and Prospects (pp. 253-289). Nueva York (EUA): Springer.

(03 June 2020). Convention on International Trade in Endangered Species of Wild Fauna and Flora. Appendices I, II and III. Retrieved from: https://cites.org/eng/app/appendices.php

Cuaron, A. D., Shedden, A., Rodriguez-Luna, E., de Grammont, P.C., Link, A., Palacios, E., Morales, A., \& Cortes-Ortiz, L. (2008a).Alouatta palliata . The IUCN Red List of Threatened Species 2008: e.T39960A10280447. Retrieved from: https://dx.doi.org/10.2305/IUCN.UK.2008.RLTS.T39960A10280447.en.

Cuaron, A. D., Morales, A., Shedden, A., Rodriguez-Luna, E., de Grammont, P. C., \& Cortes-Ortiz L. (2008b). Ateles geoffroyi . The IUCN Red List of Threatened Species 2008: e.T2279A9387270. Retrieved from: https://dx.doi.org/10.2305/IUCN.UK.2008.RLTS.T2279A9387270.en.

Cuaron, A. D., Morales, A., Shedden, A., Rodriguez-Luna, E., \& de Grammont, P. C. (2008c). Cebus capucinus ssp. capucinus. The IUCN Red List of Threatened Species 2008: e.T43934A10841636. Retrieved from: https://dx.doi.org/10.2305/IUCN.UK.2008.RLTS.T43934A10841636.en.

Cuaron, A. D., Morales, A., Shedden, A., Rodriguez-Luna, E., \& de Grammont, P. C. (2008d). Saimiri oerstedii ssp.citrinellus. The IUCN Red List of Threatened Species 2008: e.T19841A9023545. Retrieved from: https://dx.doi.org/10.2305/IUCN.UK.2008.RLTS.T19841A9023545.en.

Cuaron, A. D., Morales, A., Shedden, A., Rodriguez-Luna, E., \& de Grammont P. C. (2008e). Saimiri oerstedii ssp. oerstedii . The IUCN Red List of Threatened Species 2008: e.T19840A9023408. Retrieved from: https://dx.doi.org/10.2305/IUCN.UK.2008.RLTS.T19840A9023408.en.

De Thoisy, B., Demar, M., Aznar, C., \& Carme, B. (2003). Ecologic correlates of Toxoplasma gondii exposure in free-ranging neotropical mammals. J. Wildl. Dis. 39:456 - 459.

De Thoisy, B., Vogel, I., Reynes, J. M., Pouliquen, J. F., Carme, B., Kazanji, M., Vie J. C. (2001). Health evaluation of translocated free-ranging primates in French Guiana. American Journal of Primatology, 54, $1-16$.

Desmonts, G., \& Remington, J. (1980). Direct agglutination test for diagnosis of Toxoplasma infection: method for increasing sensitivity and specificity. Journal of Clinical Microbiology, 11, 562-568.

Dubey, J. P. (2010). Toxoplasmosis of animals and humans. 2nd ed. Boca Raton (FL): CRC Press Taylor and Francis Group, 338 p.

Dubey, J. P., \& Beattie, C.P. (1988). Toxoplasmosis of animals and man. Florida: CRC Press. 220 p.

Dubey, J. P., \& Desmonts, G. (1987). Serological responses of equids fed Toxoplasma gondii oocysts. Equine Veterinary Journal, 19, 337-339.

Dubey JP, Miller NL, \& Frenkel JK. 1970. The Toxoplasma gondii oocyst from cat feces. J Exp Med. 132:636-662.

Dubey, J.P., Thulliez, P., Weigel, R.M., Andrews, C.D., Lind, P. \& Powell, E.C. (1995). Sensitivity and specificity of various serologic tests for detection of Toxoplasma gondii infection in naturally infected sows. American Journal of Veterinary Research 56: 1030- 1036.

Dubey, J. P., Laurin, E., \& Kwok, O. C. H. (2016). Validation of the modified agglutination test for the detection of Toxoplasma gondii in free-range chickens by using cat and mouse bioassay. Parasitology 143: $314-319$.

Ekanayake, D. K., Rajapakse, R. P., Dubey, J. P., \& Dittus, W. P. (2004). Seroprevalence of Toxoplasma gondii in wild toque macaques (Macaca sinica) at Polonnaruwa, Sri Lanka. J Parasitol, 90:870-871.

Feagle, J. G. (1999). Primate adaptation and evolution. Academic, San Diego, CA 
Fragaszy, D. M., Visalberghi, E., \& Fedigan, L. M. (2004) The complete capuchin - the biology of the genus Cebus . Cambridge University Press, Cambridge, UK

Frenkel, J. K., Ruiz, A., \& Chinchilla, M., 1975. Soil survival of Toxoplasma oocysts in Kansas and Costa Rica. Am. J. Trop. Med. Hyg. 24, 439-443.

Gamarra, J. A., Cabezon, O., Pabon, M., Arnal, M. C., Luco, D. F., Dubey, J. P., Gortazar, C., \& Almeria, S. (2008). Prevalence of antibodies against Toxoplasma gondii in roe deer from Spain. Vet Parasitol. 153(12):152-6.

Garcia, J. L., Svoboda, W. K., Chryssafidis, A. L., de Souza Malanski, L., Shiozawa, M. M., de Moraes Aguiar, L., Teixeira, G. M., Ludwig, G., da Silva, L. R., Hilst, C., \& Navarro, I. T. (2005). Seroepidemiological survey for toxoplasmosis in wild New World monkeys (Cebus spp., Alouatta caraya) at the Parana river basin, Parana State, Brazil. Veterinary Parasitology, 133, 307-311.

Gilbert, K. A., \& Stouffer P. C. (1989). Use of a ground-water source by mantled howler monkeys (Alouatta palliata ). Biotropica 21:380 .

Glander, K., Fedigan, L.M., Fedigan, L., \& Chapman, C. (1991). Field methods for capture and measurement of three monkey species in Costa Rica. Folia Primatologica, 57, 70-82

Gonzalez, F., \& Lobo S. (1999). Breve descripcion del estado de los recursos forestales de Costa Rica. En: Kleinn C y Davis R. Memoria del Taller sobre el programa de evaluacion de los recursos forestales en once paises latinoamericanos. Turrialba (Costa Rica): FAO, SIDA, CATIE. 75 p.

Gray, J. J., Balfour, A. H., \& Wreghitt, T. G. (1990). Evaluation of a commercial latex agglutination test for detecting antibodies to Toxoplasma gondii . Serodiagno Immunother Infect Dis. 4:335-340.

Gutierrez, C., Lucke, O., \& Solorzano, R. (1985). Integracion de la Conservacion con el Desarrollo en el Proyecto de Riego Arenal-Tempisque (un estudio de caso). CATIE- IUCN. Turrialba, Costa Rica. Vols I y II.

Hejlicek, K., Literak, I., \& Nezval, J. (1997). Toxoplasmosis in wild mammals from the Czech Republic. Journal of Wildlife Diseases , 33, 480-485.

Hijmans, R. J., Cameron, S. E., Parra, J. L., Jones, P.G., \& Jarvis, A. (2005) Very high resolution interpolated climate surfaces for global land areas. International Journal of Climatology, 25, 1965- 1978. www.worldclim.org

Holdridge, L. R., \& Grenke, W. C. (1971). Forest environments in tropical life zones: a pilot study. Pergamon Press, New York

Horn, J. A., Mateus-Pinilla, N., Warner, R. E., \& Heske, E. J. (2011). Home range, habitat use, and activity patterns of free-roaming domestic cats. J Wildl Manag. 75:1177-85.

Hubalek, Z. (2005). North Atlantic weather oscillation and human infectious diseases in the Czech Republic, 1951-2003. Eur. J. Epidemiol. 20, 263-270.

Instituto Nacional de Biodiversidad (INBIO). (03 June 2020). Biodiversity in Costa Rica. Retrieved from: http://www2.inbio.ac.cr/en/biod/bio_biodiver.htm

La Gaceta 2006. Decreto ejecutivo Ndeg 33-106 MINAE. Poder ejecutivo de Costa Rica. La Gaceta Ndeg 133. May 30, 2006.

Leite, T. N., Maja, T. de A., Ovando, T. M., Cantadori, D. T., Schimidt, L. R., Guercio, A. C., Cavalcanti, A., Lopes, F. M., Da Cunha, I. A., \& Navarro, I. T. (2008). Occurrence of infection Leishmania spp. and Toxoplasma gondii in monkeys (Cebus apella) from Campo Grande, MS. Revista Brasileira de Parasitologia Veterinaria,17(1), 307-310. 
Lindsay, D. S., and Dubey, J. P. (2007). Toxoplasmosis in wild and domestic animals. En: Weiss, L. M., \& Kim, K. (eds.), Toxoplasma gondii: the model apicomplexan. Perspectives and Methods (pp. 133-152). London, UK: Academic Press.

McKinney, T. 2011. The effects of provisioning and crop-raiding on the diet and foraging activities of human-commensal white-faced capuchins (Cebus capucinus ). American Journal of Primatology. 73:439-448

MINAET, FONAFIFO. 2012. Estudio de cobertura forestal de Costa Rica 2009-2010. Cooperacion Financiera entre Alemania y Costa Rica. Proyecto: Programa Forestal Huetar Norte. Contrato de Aporte Financiero Ndeg 199966 268. San Jose, Costa Rica

Molina, C. V., Catao-Dias, J. L., Ferreira Neto, J. S., Vasconcellos, S. A., Gennari, S. M., do Valle, R. D. R., de Souza, G. O., de Morais, Z. M., Vitaliano, S. N., Strefezzi, R. D. F., \& Bueno, M. G. (2014). Sero-epidemiological survey for brucellosis, leptospirosis, and toxoplasmosis in free-ranging Alouatta caraya and Callithrix penicillata from Sao Paulo State, Brazil. Journal of Medical Primatology, 43, 197-201.

Nardoni, S., Angelici, M. C., Mugnaini, L., \& Mancianti, F. (2011). Prevalence of Toxoplasma gondii infection in Myocastor coypus in a protected Italian wetland. Parasites and Vectors 23: 240-243.

Niewold, F. J. J. (1986). Voedselkeuze, terreingebruik en aantalsregulatie van in het veld operende huiskatten Felis catus L., 1758. Lutra 29, 145-187.

Ottaviani, D., Cairns, S. C., Oliverio, M., \& Boitani, L. (2006). Body mass as a predictive variable of homerange size among Italian mammals and birds. J Zool 269:317-330.

Pagiola, S. (2008). Payments for environmental services in Costa Rica. Ecological Economics. 65 (4): $712-724$.

Pires, J. S., Ribeiro, C. T., Carvalho Filho, P. R., Pissinatti, A., Flausino, W., \& Lopes, C. W. G. (2012). Infection by Toxoplasma gondii. Pesquisa Veterinaria Brasileira, 32(10), 1041-1044.

Rajendran, C., Sub, C., \& Dubey, J. P. (2012). Molecular genotyping of Toxoplasma gondii from Central and South America revealed high diversity within and between populations Infection. Genetics and Evolution 12: $359-368$

Rego, W. M. F., Costa, J. G. L., Baraviera, R. C. A., Pinto, L. V., Bessa, G. L., Lopes, R. E. N., Silveira, J. A. G., \& Vitor, R. W. A. (2018). Genetic diversity of Toxoplasma gondii isolates obtained from free-living wild birds rescued in Southeastern Brazil. International Journal for Parasitology: Parasites and Wildlife 7 (3): 432-438.

Remington, J. S., Thulliez, P., \& Montoya, J. G. (2004). Recent developments for diagnosis of toxoplasmosis. Journal of Clinical Microbiology 42, 941

R Core Team. (2013). R: A language and environment for statistical comput- ing. Vienna, Austria: R Foundation for Statistical Computing. http:// www.R-project.org/

Roberts, L. S., \& Janovy, J. R., J. (2000). Phylum Apicomplexa: Gregarines, Coccidia, and related organisms. En Foundations of Parasitology. EUA: The McGraw-Hill Companies, Inc., p. 117-140.

Ruiz, A., Frenkel, J. K., \& Cerdas, L. (1973). Isolation of toxoplasma from soil. J Parasitol. 59, 204-6.

Salant, H., \& Spira, D. T. (2004). A cross-sectional survey of anti-Toxoplasma gondii antibodies in Jerusalem cats. Vet Parasitol. 124:167-177.

Seefeldt, S. L., Kirkbride, C. A., \& Dubey, J. P. (1989). Comparison of enzyme-linked immunosorbent assay, indirect fluorescent antibody test, and direct agglutination test for detecting Toxoplasma gondiiantibodies in naturally aborted ovine fetuses. J Vet Diagn Invest. 1:124-127. 
Shaapan, R. M., El-Nawawi, F. A., \& Tawfik, M. A. A. (2008). Sensitivity and specificity of various serological tests for the detection of Toxoplasma gondii infection in naturally infected sheep. Vet Parasitol. 153:359-362.

SINAC (Sistema Nacional de Areas de Conservacion). (2008). Guia practica para el diseno, oficializacion y consolidacion de corredores biologicos en Costa Rica. San Jose. 53 p.

Smith, D. D., \& Frenkel, J. K. (1995). Prevalence of antibodies to Toxoplasma gondii in wild mammals of Missouri and east central Kansas: Biologic and ecologic considerations of trans- mission. Journal of Wildlife Diseases 31: 15-21.

Su, C., Evans, D., Cole, R. H., Kissinger, J. C., Ajioka, J. W., \& Sibley, L. D. 2003. Recent expansion of Toxoplasma through enhanced oral transmission. Science 299:414-416.

Tenter, A. M., Heckerothm, A. R., \& Weiss, L. M. (2000).Toxoplasma gondii : from animals to humans. International Journal for Parasitology, 30, 1217-1258.

Valentini, E. J. G., Caprara, A., Souza, S. L. P., Mattaraia, V. G. M., Gennari, S. M., Rodrigues, U. P., Francisco, F. M., \& Soares, R. M. (2004). Investigacao sorologica de infeccao por Toxoplasma gondiiem colonia de macacos da especie Macaca mulatta. Arquivos do Instituto Biologico de Sao Paulo, 71(4): 507-510.

VanWormer, E., Fritz, H., Shapiro, K., Mazeta, J. A. K., \& Conrad, P. A. (2013). Molecules to modeling: Toxoplasma gondii oocysts at the human-animal-environment interface. Comp Immunol Microb. 36: 217231.

Varela, N. (2006). Introduccion al estudio de la salud de los primates neotropicales: Modulo 4. Bogota, Colombia: Asociacion Colombiana de Primatologia.

Vethencourt, M. A., Bolanos, J. E., Chinchilla, M., Valerio, I., Loaiza, G. M., Lopez, C. M., Valerio L., \& Ramirez, J. (2019). Detection and Molecular Characterization of Three Chronic Strains of Toxoplasma gondii, Isolated In Costa Rica. EC Microbiology 15.8: 846-855.

Vitaliano, S. N., Soares, H. S., Minervino, A. H. H., Santos, A. L. Q. , Werther, K., Marvulo, M. F. V., Siqueira, D. B., Pena, H. F. J., Soares, R. M. S. C., \& Gennari, S. M. (2014). Genetic characterization of Toxoplasma gondii from brazilian wildlife revealed abundant new genotypes. Int. J. Parasitol.: Parasites Wildl. 3, 276-283.

Wainwright, M. (2007). The mammals of Costa Rica, a natural history and field guide. Ithaca (Nueva York): Zona Tropical. 488 p.

West, G., Heard, D., \& Caulkett, N. (2007). Zoo Animal and Wildlife Immovilization and Anesthesia. Iowa: Blackwell.

Wolfe, N. D., Escalante, A. A., Karesh, W. B., Kilbourn, A., Spielman, A., \& Lal, A. A. (1998). Wild primate populations in emerging infectious disease research: the missing link? Emerging Infectious Diseases, 4(2): $149-158$.

Xiao J \&Yolken RH. (2015), Strain hypothesis of Toxoplasma gondii infection on the outcome of human diseases. Acta Physiologica 213: 828-845.

Table 1. Independent variables chosen for Generalized Linear Models (GLM) Toxoplasma gondii exposure in wild Alouatta palliata and Cebus imitator.

Table 2. Generalized Linear Models that explain intrinsic, environmental and anthropogenic attributes on Toxoplasma gondiiseroprevalence in Alouatta palliata and Cebus imitator .

Table 3. Prevalence of Toxoplasma gondii antibodies in captive and wild Neotropical primates in Costa Rica according to species and sex. Samples of Saimiri oerstedii $(\mathrm{n}=5)$ were excluded. 
Table 4. Seroprevalence of Toxoplasma gondii in captive Neotropical Primates from Costa Rica according to site and species.

Table 5. Seroprevalence of Toxoplasma gondii in wild Neotropical Primates from Costa Rica according to sample site and species.

Table 6. Antibody titers of Toxoplasma gondii IgG in Neotropical primates of Costa Rica

Figure 1. Map of Toxoplasma gondii seropositive wild Neotropical primates (NP) from Costa Rica from 2000-2015: (A.) Protected areas, (B.) Forest Cover, (C.) Precipitation. Gray circles: seronegative NP, pink circles: seropositive NP.

\section{Hosted file}

niehaus et al. 2020 - Table 1.docx available at https://authorea.com/users/332419/ articles/458882-relationship-between-toxoplasma-gondii-exposure-and-forest-cover-andprecipitation-in-neotropical-primates-of-costa-rica

\section{Hosted file}

niehaus et al. 2020 - Table 2.docx available at https://authorea.com/users/332419/ articles/458882-relationship-between-toxoplasma-gondi-exposure-and-forest-cover-andprecipitation-in-neotropical-primates-of-costa-rica

\section{Hosted file}

Niehaus et al. 2020 - Table 3.docx available at https://authorea.com/users/332419/ articles/458882-relationship-between-toxoplasma-gondi-exposure-and-forest-cover-andprecipitation-in-neotropical-primates-of-costa-rica

\section{Hosted file}

Niehaus et al. 2020 - Table 4.docx available at https://authorea.com/users/332419/ articles/458882-relationship-between-toxoplasma-gondii-exposure-and-forest-cover-andprecipitation-in-neotropical-primates-of-costa-rica

\section{Hosted file}

Niehaus et al. 2020 - Table 5.docx available at https://authorea.com/users/332419/ articles/458882-relationship-between-toxoplasma-gondii-exposure-and-forest-cover-andprecipitation-in-neotropical-primates-of-costa-rica

\section{Hosted file}

Niehaus et al. 2020 - Table 6.docx available at https://authorea.com/users/332419/ articles/458882-relationship-between-toxoplasma-gondii-exposure-and-forest-cover-andprecipitation-in-neotropical-primates-of-costa-rica 


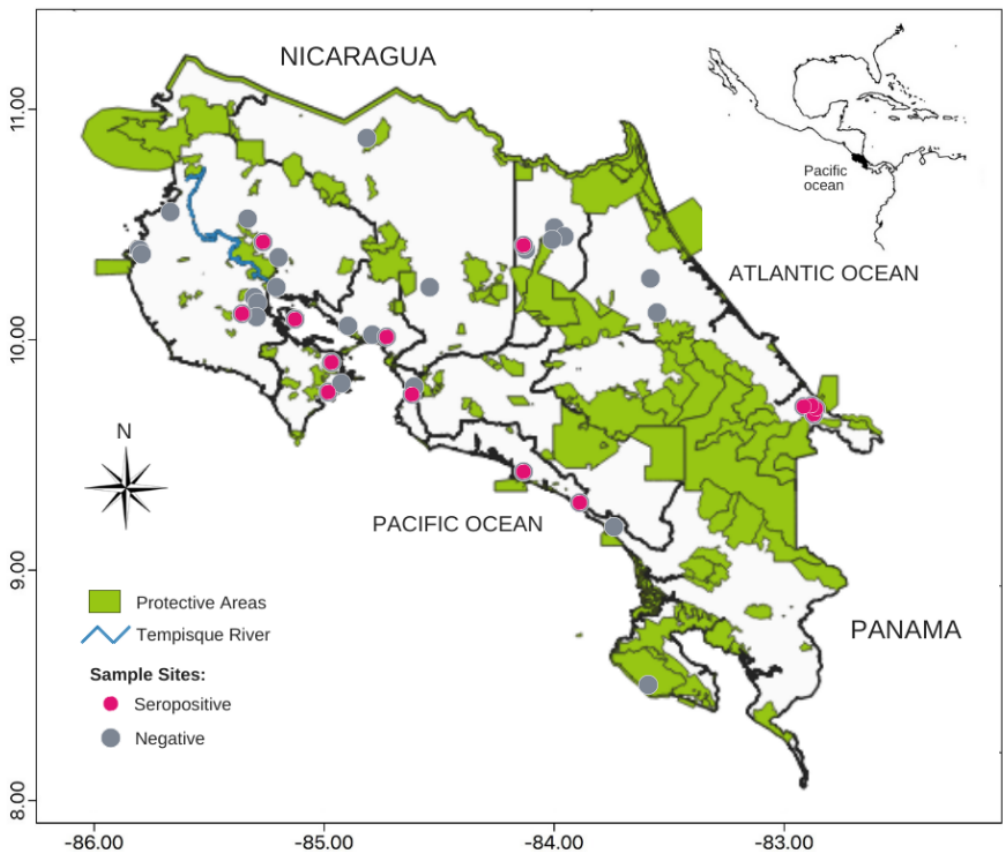

A.

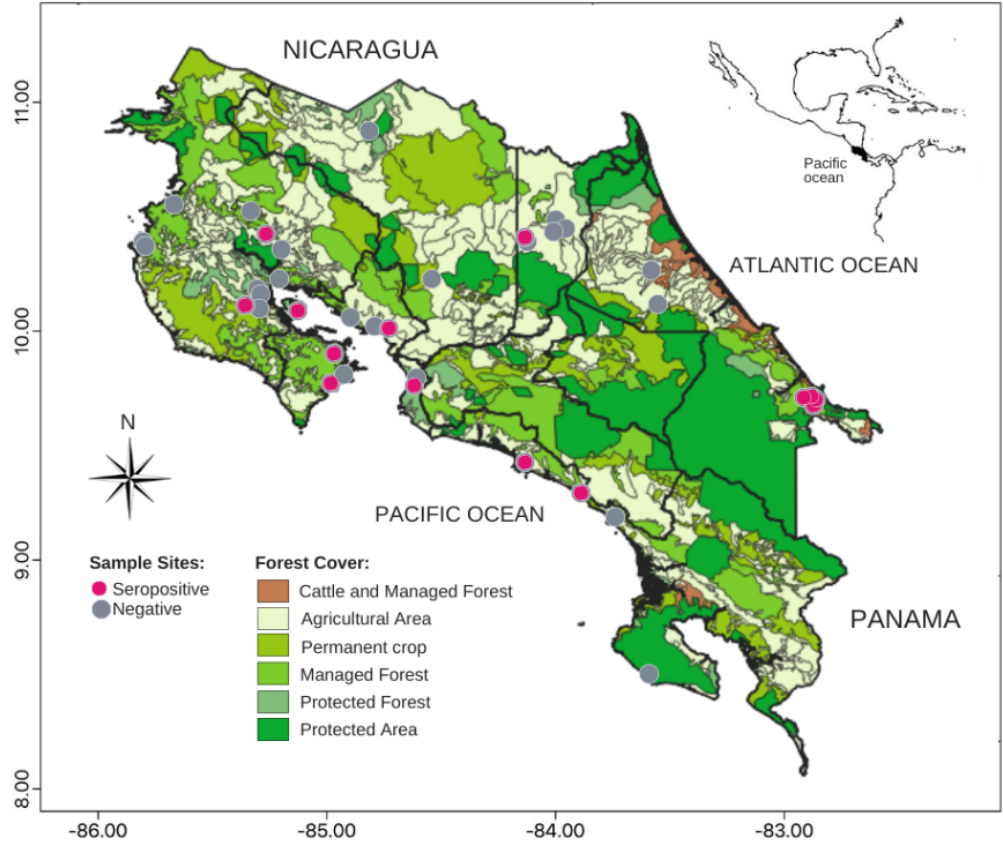

B.

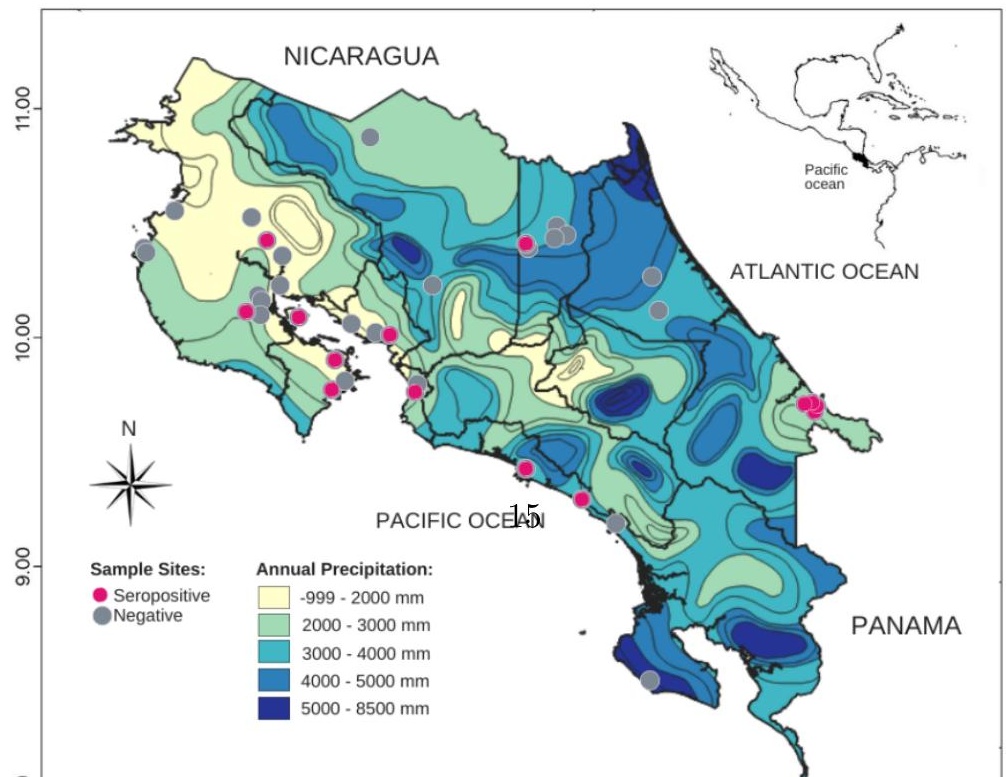

C. 